\title{
PENGEMBANGAN EKSIPIEN SEDIAAN TABLET DARI PATI SINGKONG TERMODIFIKASI SECARA FISIKOKIMIA UNTUK PENINGKATAN SIFAT FARMASETIKANYA
}

\section{THE DEVELOPMENT OF TABLET EXCIPIENT FROM CASSAVA STARCH MODIFIED PHYSICOCHEMICALLY TO IMPROVE PHARMACEUTICAL CHARACTHERISTIC}

\author{
Mega Octavia $^{1}$, Yandi Syukri ${ }^{2}$, Feris Firdaus ${ }^{3}$ \\ 1. Program Studi Farmasi, Fakultas Ilmu Kedokteran dan Kesehatan, Universitas \\ Muhammadiyah Yogyakarta \\ 2. Program Studi Farmasi, Fakultas Matematika dan Ilmu Pengetahuan Alam, \\ Universitas Islam Indonesia \\ 3. Direktorat Penelitian dan Pengabdian Masyarakat, Universitas Islam Indonesia
}

Submitted : 25 Juli 2018 Reviewed : 14 Februari 2019 Accepted : 16 Maret 2019

\begin{abstract}
ABSTRAK
Pati singkong alami sangat potensial untuk dikembangkan di industri farmasi. oleh karena itu, harus memenuhi spesifikasi persyaratan farmasetika yang diinginkan oleh industri farmasi agar dapat digunakan sebagai eksipien tablet. Penelitian ini bertujuan untuk mengembangkan eksipien sediaan tablet dari pati singkong yang dimodifikasi secara fisikokimia untuk meningkatkan sifat farmasetikanya. Penelitian ini dilakukan dalam 3 tahap, pertama, tahap ekstraksi pati singkong, kedua, tahap modifikasi pati singkong dengan panas langsung, penambahan pentanol-1 dan penambahan asam asetat, ketiga, analisis sifat farmasetika. Analisis hasil menggunakan metode deskriptif-komparatif. Hasil uji kompaktibilitas, pati termodifikasi dengan pentanol-1 memiliki kekerasan yang lebih baik $(1,69 \pm 0,29)$ di bandingkan dengan pati alami $(1,08 \pm 0,09)$. Sedangkan untuk hasil pengukuran partikel menunjukkan bahwa pati termodifikasi dengan asam asetat memiliki ukuran partikel lebih besar $(12,5 \pm 1,9)$ dibandingkan dengan pati alami $(11,9 \pm 1,28)$. Pati termodifikasi dengan pentanol mempunyai sifat alir yang lebih baik $(\mathrm{CI}=18,9 \% \pm 1,52)$ dari pati modifikasi lain akan tetapi masih lebih baik pada pati alami (CI=13,2\% $\pm 2,99)$. Dari hasil analisis dapat disimpulkan bahwa karakteristik pati singkong termodifikasi potensial untuk dijadikan sebagai pengikat dan penghancur sediaan tablet dibandingkan dengan pati yang tidak di modifikasi.
\end{abstract}

Kata kunci : Singkong, patitermodifikasi, sifat farmasetik

\begin{abstract}
Natural cassava starch was very potential to be developed in the pharmaceutical industry, therefore; it must meet the pharmaceutical requirements specifications desired by the pharmaceutical industry to be used as excipient tablets. This study aims to develop excipients of tablet preparations of modified cassava starch to improve its pharmaceutical properties. This research was conducted in 3 stages, first, cassava starch extraction, second,
\end{abstract}


modification of cassava starch with direct heat, the addition of pentanol-1 and addition of acetic acid, third, pharmaceutics analysis. Analysis of the results using descriptivecomparative method.The results of the compatibility test, modified starch with pentanol-1 had a higher hardness $(1.69 \pm 0.29)$ in comparison with natural starch $(1.08 \pm 0.09)$. As for particle measurement results showed that modified starch with acetic acid had a larger particle size $(12.5 \pm 1.9)$ than natural starch $(11.9 \pm 1.28)$. Modified starch with pentanol has better flow properties $(\mathrm{CI}=18.9 \% \pm 1.52)$ than other modified starch but is still better on natural starch $(\mathrm{CI}=13.2 \% \pm 2.99)$. It can be concluded that the characteristics of potentially modified cassava starch to serve as binder and disintegrant tablets compared with unmodified starch.

Keyword : Cassava starch, modified starch, pharmaceutical charactheristic

\section{Penulis korespondensi :}

\section{Mega Octavia}

Program Studi Farmasi, Fakultas Ilmu Kedokteran dan Kesehatan

Universitas Muhammadiyah Yogyakarta

Email : megaoctavia88@gmail.com

\section{PENDAHULUAN}

Singkong (Manihot esculenta Crantz.) berasal dari Amerika Selatan yang hidup subur pada daerah tropis dan subtropis. Singkong merupakan tanaman pangan yang sangat penting di antara tanaman pertanian yang lain karena dalam pemeliharaannya mudah dan produktif (Gusnimar, 2003; Onyango dkk., 2013; Winarno,1986). Modifikasi secara fisik dan kimia pati dari umbi-umbian lokal khususnya pati singkong merupakan upaya derivatisasi dari pati aslinya menjadi berbagi produk turunannya yang memiliki karakteristik farmasetik yang lebih baik khususnya untuk bahan baku pembuatan tablet. Di berbagai negara di dunia seperti Thailand, China, Brazil, Afrika, dan Asia secara umum, upaya modifikasi pati tersebut menjadi primadona untuk menghasilkan berbagai derivatnya yang memiliki karakteristik beragam sesuai dengan fungsi penggunaannya di berbagai bidang. Satu hal penting yang menjadi keprihatinan bangsa ini adalah bahwa Indonesia sebagai penghasil pati dari umbi-umbian yang besar tetapi dalam fakta penggunaan bahan baku pembuatan tablet masih impor 100 $\%$ pati termodifikasi secara fisik dan kimia dari berbagai negara di dunia. Setelah dikaji secara mendalam, diperoleh jawaban, yakni teknologi modifikasi pati secara fisik dan kimia di Indonesia tidak berkembang dengan baik.

Pati telah lama digunakan orang baik sebagai bahan makanan maupun bahan tambahan dalam sediaan farmasi. Penggunaan pati dalam bidang farmasi terutama pada formula sediaan tablet baik sebagai bahan pengisi, penghancur, maupun sebagai bahan pengikat. Namun dalam pembuatan tablet cetak langsung, pati tidak dapat digunakan karena pati berupa serbuk halus dan dalam sediaan aslinya pati tidak mempunyai sifat alir dan daya kompresibilitas yang baik (Anonim, 2006). Hal ini tidak lepas dari pengaruh komponenkomponen yang menyusun pati terutama amilosa dan amilopektin, kedua komponen ini dapat dikatakan homogen secara kimia tetapi masih heterogen dalam ukuran molekul, derajat percabangan, rantai, susunan, dan keacakan rantai cabang (Ikhsan, 1996; Gusnimar, 2003).

Modifikasi secara fisik dan kimia pati dari umbi-umbian lokal khususnya pati singkong dan pati ubi jalar merupakan upaya derivatisasi dari pati aslinya menjadi berbagi produk turunannya yang memiliki karakteristik farmasetik yang lebih baik khususnya untuk 
bahan baku pembuatan tablet (Wlodarski dkk., 2016). Di berbagai negara di dunia seperti Thailand, China, Brazil, Afrika, dan Asia, upaya modifikasi pati tersebut menjadi primadona untuk menghasilkan berbagai derivatnya yang memiliki karakteristik beragam sesuai dengan fungsi penggunaannya di berbagai bidang. Indonesia sebagai penghasil pati dari umbiumbian yang besar namun sebagian besar bahan baku pembuatan tablet masih impor. Setelah dikaji secara mendalam, diperoleh jawaban, yakni teknologi modifikasi pati secara fisik dan kimia di Indonesia tidak berkembang dengan baik.

Telah dilakukan kajian terhadap pati yang dimodifikasi sesuai dengan karakteristik pati yang diinginkan industri. Pati yang dimodifikasi dengan senyawa asetat menghasilkan pati yang memiliki \% kelarutan dan \% swelling yang lebih baik dibandingkan pati yang tidak dimodifikasi serta membutuhkan biaya produksi yang lebih ekonomis sehingga sangat menguntungkan digunakan untuk skala industri khususnya di bidang farmasi (Aziz dkk., 2004 dan Dzulkefly dkk., 2007). Selain itu penelitian yang dilakukan Ayucitra dkk. (2009) pada pati sagu dan jagung yang dimodifikasi secara asetilasi diperoleh pati tersebut memiliki nilai solubility yang lebih baik seiring dengan meningkatnya suhu pemanasan. Unruk modifikasi dengan senayawa butanol pada pati singkong juga telah dilakukan dan diperoleh pati yang telah dimodifikasi tersebut memiliki sifat alir yang baik ( Ben dkk., 2007). Pati lokal membutuhkan proses modifikasi secara fisik dan kimia untuk menghasilkan derivat yang memiliki karakteristik farmasetika yang lebih baik dan spesifik khususnya untuk pembuatan tablet. Dalam penelitian ini akan dilakukan upaya pengembangan eksipien sediaan farmasi dari amilum/pati umbi-umbian lokal termodifikasi secara fisikokimia untuk peningkatan sifat farmasetikanya (Syukri dan Firdaus, 2009).

Penelitian ini bertujuan untuk mengembangkan eksipien sediaan tablet dari pati singkong yang dimodifikasi secara fisikokimia untuk meningkatkan sifat farmasetikanya.

\section{METODE PENELITIAN}

\section{Alat dan Bahan}

Bahan-bahan yang dalam penelitian ini antara lain Ubikayu/singkong (Manihot esculenta Crantz.) di daerah perkebunan singkong di Sleman, amilum standard Amprotab (kualitas farmasetis), aquadest, Iodium LP, etanol (96\%), pentanol-1 (kualitas pro analisis), asam asetat glasial (kualitas pro analisis), di peroleh dari alfa kimia, Yogyakarta.

Alat yang digunakan dalam penelitian ini adalah: mesin penggiling, seperangkat alat gelas, kain penyaring, stop watch, lemari pengering, oven, pengayak mesh 20, 40, 60, dan 80, neraca analitik tipe Dragon 204 (Mettler Toledo), termometer (Celcius), kompor listrik, cawan porselen, mesin tablet, corong alir, Hardness Tester (Vanguard), tapped density, mikroskop optik yang dilengkapi kamera, sonifikasi.

\section{Jalannya Penelitian}

\section{Ekstraksi Pati Ubi Kayu/singkong}

Ekstraksi pati singkong terdiri atas beberapa tahapan, dimana pati diektraksi dengan cara basah. Ekstraksi pati cara basah terdiri atas tahapan pembersihan, pengupasan, pencucian, perendaman, dan penghancuran pati singkong yang dilanjutkan dengan proses pemisahan pati melalui, penyaringan, dan pengendapan. Pati singkong yang diperoleh kemudian dikeringkan, digiling, dan diayak (Rahman, 2007). 


\section{Modifikasi Secara Fisikokimia Pati Singkong}

a. Modifikasi dengan pemanasan/pengukusan secara langsung (alpha starch)

Proses modifikasi pati/amilum yang dihasilkan menjadi pati alfa yakni dapat dilakukan dengan cara memanaskan 125 gram pati tersebut dalam media pengukus secara langsung selama 30 menit pada suhu $120^{\circ} \mathrm{C}$. Selanjutnya dimasukkan dalam oven pada suhu $50{ }^{\circ} \mathrm{C}$ selama $1 \times 24$ jam. Kemudian Pati diayak dan dikemas siap untuk dijadikan sebagai bahan baku pembuatan eksipien tablet (Ayucitra dkk., 2009). Kemudian hasil pati modifikasi dianalisis.

b. Modifikasi dengan pentanol-1 (pemutusan ikatan amilosa-amilopektin)

Proses modifikasi pati/amilum yang dihasilkan dengan cara pemutusan ikatan antara amilosa dan amilopektin (Ben dkk., 2007), yakni dapat dilakukan dengan mencampurkan $125 \mathrm{ml}$ pentanol-1 ke dalam 125 gram pati kemudian diblending dalam pencampur putar selama 30 menit dalam suhu kamar. Selanjutnya dilakukan pemisahan antara cairan pentanol-1 dengan pati, lalu pati dikeringkan dalam oven, dan di ayak dengan mesh 80 (Firdaus dkk., 2006; Sriroth dkk., 2002). Kemudian pati hasil modifikasi dianalisis.

Adapun prinsip dari modifikasi ini yaitu senyawa pentanol-1 akan berikatan dengan gugus -o- pada atom $\mathrm{C}$ alfa yang kemudian akan memutus ikatan alfa-1,4 glikosidik yang menghubungkan antara glukosa yang satu dengan glukosa yang lain. Sehingga dihasilkan pati dengan ukuran molekul yang lebih kecil dari pati singkong alami.

c. Modifikasi secara asetilasi dengan asam asetat (pati asetat)

Pati termodifikasi asam dibuat dengan mencampur pati dengan asam asetat pada suhu kamar, pada suhu sekitar $27^{\circ} \mathrm{C}$. Pati yang digunakan sebanyak 125 gram, lalu ditambahkan aquades sebanyak $375 \mathrm{ml}$, campuran tersebut di aduk sampai pati benarbenar tercampur semua. Selanjutnya asam asetat glasial sebanyak $8 \mathrm{ml}$ ditambahkan secara perlahan-lahan ke dalam campuran tersebut sambil di aduk, dibiarkan selama 30 menit dengan beberapa kali di aduk. Kemudian disaring sebanyak 3 kali, dipisahkan antara cairan dengan patinya, lalu pati tersebut di keringkan dalam oven. Di ayak dengan mesh 80 (Voight, 1984). Kemudian pati hasil modifikasi di analisis.

Adapun prinsip modifikasi ini yaitu menyisipkan gugus asetil dari senyawa asam asetat yang akan menggantikan gugus $-\mathrm{OH}$ yang terdapat pada pati melalui reaksi asetilasi, diperoleh pati yang terasetilasi atau dinamakan dengan pati asetat, dimana hal ini akan mengurangi kekuatan ikatan hidrogen di antara pati dan menyebabkan granula pati mudah larut dalam air.

\section{Analisis Sifat Farmasetika secaraFisikokimia}

Analisis yang dilakukan seperti organoleptis, kelarutan dengan menggunakan larutan etanol, identifikasi iodium dengan mengamati perubahan warna, ukuran partikel dengan menggunakan mikroskop elektrik dengan pembesaran 40x, sifat alir serbuk, uji pengetapan dengan motorized tapping device (ohwoavworhua dan Alelakun, 2005), kompaktibilitas dengan hardness tester.

\section{HASIL DAN PEMBAHASAN}

\section{Karakteristik Sifat Fisika kimia Pati singkong}

Sebelum dilakukan modifikasi dan analisis terhadap singkong/ubi kayu sebagai objek uji terlebih dahulu dilakukan uji pendahuluan dengan melakukan determinasi tanaman singkong. Setelah dilakukan determinasi terhadap tanaman singkong sebagai bahan baku 
pembuatan pati termodifikasi diperoleh hasil bahwa tanaman singkong yang digunakan pada penelitian ini termasuk jenis Manihot esculenta Crantz. Adapun hasil data uji kualitatif dari pati modifikasi singkong, pati alami, dengan pati pembanding yaitu amprotab dapat dilihat pada tabel I di bawah ini.

\section{Organoleptis}

Pati dengan penambahan pentanol berbentuk serbuk yang lebih halus dan lebih lengket di bandingkan dengan semua modifikasi dan pati alami. Hal ini kemungkinan disebabkan oleh ukuran pati yang di putus oleh pentanol menjadi ukuran yang lebih kecil sehingga pati memiliki gaya adhesif dan kohesif yang menyebabkan pati yang dihasilkan terasa lebih halus dan lengket. Tekstur dari pati modifikasi dengan pentanol-1 sama dengan pati pembanding yaitu Amprotab.

Adapun hasil data uji kualitatif dari pati modifikasi singkong, pati alami, dengan pati pembanding yaitu amprotab dapat di lihat pada tabel I di bawah ini.

Tabel I. Hasil Uji Kualitatif Pati Alami, Pati Modifikasi dan Amprotab

\begin{tabular}{|c|c|c|c|}
\hline No & Pemeriksaan & Hasil & Keterangan \\
\hline 1. & $\begin{array}{l}\text { Organoleptis } \\
\text { a. Bentuk } \\
\text { b. Warna } \\
\text { c. Bau } \\
\text { d. Rasa }\end{array}$ & $\begin{array}{l}\text { Pati modifikasi, pati alami, } \\
\text { dan pati standard amprotab } \\
\text { memilki bentuk serbuk, } \\
\text { warna putih, tidak berbau } \\
\text { dan tidak berasa }\end{array}$ & $\begin{array}{l}\text { Sesuai dengan persyaratan } \\
\text { yaitu berbentuk serbuk } \\
\text { halus, putih tidak berbau } \\
\text { dan tidak berasa (Anonim, } \\
\text { 1995). }\end{array}$ \\
\hline 2. & $\begin{array}{l}\text { Kelarutan } \\
\text { a. Aquadest } \\
\text { b. Etanol }\end{array}$ & $\begin{array}{l}\text { Pati modifikasi, pati alami, } \\
\text { dan pati standard amprotab } \\
\text { praktis tidak larut dalam } \\
\text { aquadest dan etanol }\end{array}$ & $\begin{array}{l}\text { Sesuai dengan } \\
\text { persyaratanya itu pati } \\
\text { praktis tidak dapat larut } \\
\text { dalam air dingin dan } \\
\text { etanol (Anonim, 1995). }\end{array}$ \\
\hline 3. & $\begin{array}{l}\text { Identifikasi } \\
\text { iodium }\end{array}$ & $\begin{array}{l}\text { Pati modifikasi, pati alami, } \\
\text { Memberikan warna ungu } \\
\text { kecuali amprotab yang } \\
\text { memberikan warna biru. }\end{array}$ & $\begin{array}{l}\text { Sesuai dengan persyaratan } \\
\text { yakni terjadi warna biru } \\
\text { tua yang hilang pada } \\
\text { pemanasan dan timbul } \\
\text { kembali pada pendinginan } \\
\text { (Anonim, 1995). }\end{array}$ \\
\hline 4. & $\begin{array}{l}\text { Ukuranpartikel } \\
\text { a. Bentuk } \\
\text { b. Hilus }\end{array}$ & $\begin{array}{l}\text { Pati modifikasi, pati alami, } \\
\text { dan pati standard amprotab } \\
\text { memiliki bentuk partikel } \\
\text { yang bulat dengan hilus } \\
\text { berada di tengah }\end{array}$ & $\begin{array}{l}\text { Sesuai dengan persyaratan } \\
\text { yaitu Butir tunggal, agak } \\
\text { bulat, dengan hilus berada } \\
\text { di tengah berupa titik } \\
\text { (Anonim, 1995). }\end{array}$ \\
\hline
\end{tabular}

2. Kelarutan

Secara teori, pati yang dimodifikasi dengan penambahan asam asetat diharapkan dapat larut dalam air. Modifikasi pati dengan asam asetat ini merupakan modifikasi kimia pati secara asetilasi yang pada prinsipnya adalah menyisipkan gugus asetil menggantikan gugus (OH-) pada pati melalui reaksi asetilasi dimana hal ini akan mengurangi kekuatan ikatan hidrogen di antara pati dan menyebabkan granula pati menjadi lebih mengembang (swelling) dan mudah larut dalam air. Dimana telah dilakukan penelitian sebelumnya terkait modifikasi pati dengan asam asetat dan 
dihasilkan peningkatan \% solubilitas seiring dengan peningkatan konsentrasi asam asetat (Patel dkk., 2007). Adapun reaksi asetilasi dapat digambarkan sebagai berikut :

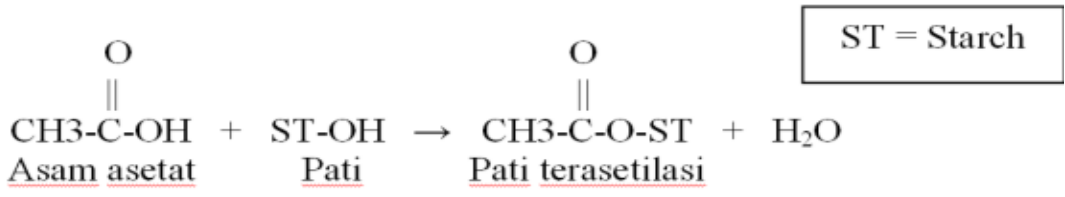

Gambar 1. Reaksi antara asam asetat dengan pati (Patel dkk., 2007).

Pada penelitian ini pati modifikasi dengan penambahan asam asetat dihasilkan pati yang tidak larut. Hal ini kemungkinan disebabkan oleh kurangnya konsentrasi dari senyawa pensubtitusi yaitu asam asetat, waktu operasi yang singkat dan faktor yang paling penting adalah tidak adanya penjagaan $\mathrm{pH}$ pada saat proses modifikasiberlangsungsehinggareaksiasetilasitidakberjalandengan optimal dan mengenai hasil kelarutan dari pati asetat perlu dilakukan penelitian lebih lanjut terkait karakteristik fisikokimianya. Hal ini sejalan dengan penelitian yang dilakukan oleh Widiawan dkk. (2013) bahwa konsentrasi asetat dan waktu perendaman berpengaruh signifikan (nilai $\mathrm{p}<0,01)$ terhadap derajat substitusi pada pati talas, semakin lama waktu perendaman dan semakin tinggi konsentrasi asetat maka meningkatkan derajat substitusi. Penelitian yang dilakukan oleh Artiani dan Avrelina (2007) juga dilaporkan bahwa lama waktu reaksi asetilasi dan semakin meningkat $\mathrm{pH}$ pada awal larutan maka pati asetat memiliki karakteristik (\% pengembangan dan \% kelarutan) yang lebih baik.

3. Ukuran partikel

Karakteristik pati dilihat dengan mikroskop optik ini dilakukan dengan perbesaran 40x, kemudian diamati bentuk molekulnya. Jenis amilum yang berbeda akan memberikan penampakan mikroskop yang berbeda dan bersifat khas. Pada pati singkong ditambahkan sedikit aqua des dan diamati pada mikroskop optik.

Adapun gambar pati modifikasi, pati alami, dan pati standar amprotab pada mikroskop optik dengan perbesaran 40x dapat dilihat pada gambar 2 dan 3 di bawah ini.

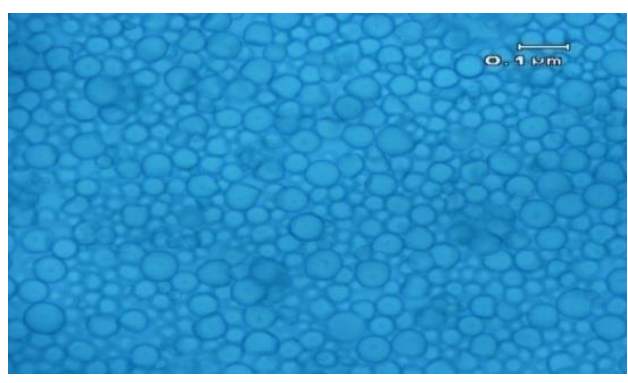

Amprotab

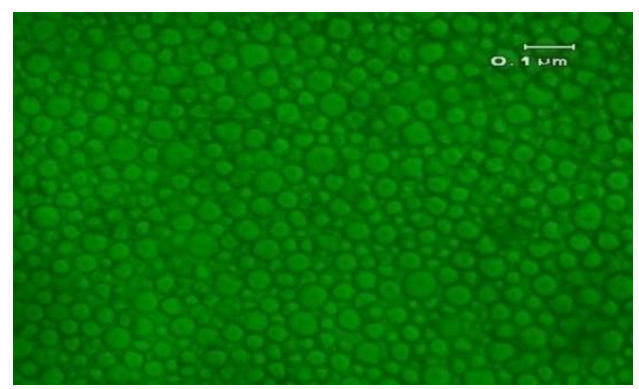

Pati singkong alami

\section{Gambar 2. Butir Pati Amprotab dan Pati Singkong Alami pada Mikroskop Optik Perbesaran 40x}

Pada pengamatan ini diketahui bahwa amprotab sebagai pembanding memiliki amilum dengan bentuk bulat dan hilus terdapat di tengah. Begitu juga halnya dengan pati singkong alami dan modifikasi dengan pemanasan selama 30 menit pada suhu $120^{\circ} \mathrm{C}$ memiliki bentuk dan hilus yang sama dengan amprotab yakni bulat. 


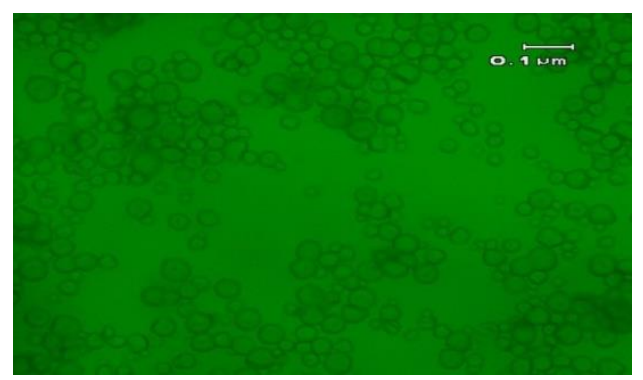

Pati modifikasi dengan pemanasan

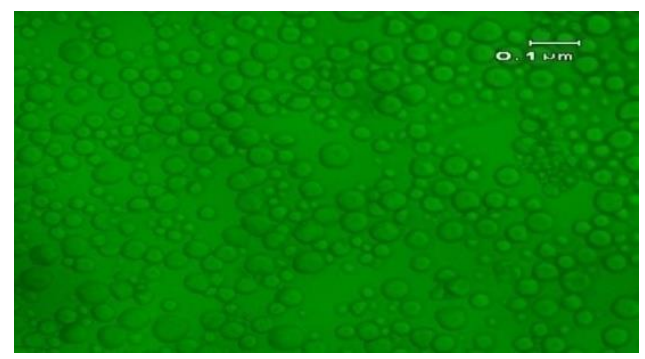

Pati modifikasi dengan pentanol-1

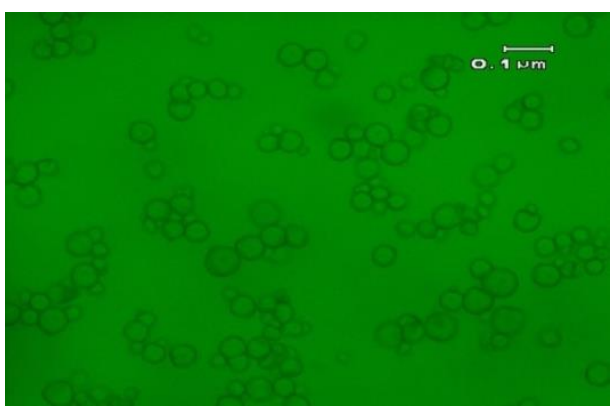

Pati modifikasi dengan asam asetat

\section{Gambar 3. Butir Pati Modifikasi Pada Mikroskop Optik Perbesaran 40x}

Pati dengan penambahan pentanol memiliki ukuran partikel paling kecil dibandingkan dengan pati modifikasi lain. Hal ini disebabkan oleh pati telah mengalami pemutusan ikatan kimia oleh pentanol pada ikatan alfa 1,4 glikosidik sehingga dihasilkan polimer pati yang lebih kecil. Pati yang mengalami modifikasi dengan asam asetat memiliki bentuk amilum yang cenderung membentuk rantai dan memiliki ukuran partikel yang lebih besar dibandingkan pati modifikasi yang lain, hal ini disebabkan oleh adanya substitusi gugus asetat ke dalam struktur molekul patidi mana gugus asetil akan menggantikan gugus - $\mathrm{OH}$ yang terdapat pada pati akibatnya bobot molekul pati modifikasi menjadi lebih besar yang dapat di lihat dariukuranmolekulnya. Hal ini membuktikan bahwa ukuran molekul pati modifikasi sudah sesuai dengan persyaratan yang telah ditentukan di Farmakope.

\section{Pemeriksaan Sifat Fisik Serbuk Pati Singkong dan Amprotab}

Sifat alir serbuk

Setelah dilakukan percobaan terhadap pati singkong diperoleh hasil yang dapat dilihat pada tabel $\mathrm{V}$ bahwa semua pati modifikasi dan pati alami tidak memberikan harga aliran serbuk, ini berarti sudut diam tidak dapat dihitung. sehingga dapat disimpulkan bahwa pati modifikasi yang diuji memiliki kecepatan alir yang sangat buruk. Hal ini dikarenakan partikel rata-rata pati modifikasi kurang dari $100 \mu \mathrm{m}$ sehingga bersifat lebih kohesiv dan pati cenderung tidak dapat bergulir ke bawah sesuai dengan gaya beratnya, selain itu juga dipengaruhi oleh gaya adhesif antara serbuk dengan corong. 
Pengetapan

Setelah dilakukan pengetapan terhadap kelima pati diketahui bahwa pati alami yang tidak dimodifikasi memiliki sifat alir baik dengan nilai indeks pemampatan 13,2\% begitu pula dengan amprotab sebagai pembanding memiliki nilai pemampatan sebesar $16 \%$. Sedangkan pati modifikasi dengan pentanol-1 dan pemanasan memiliki sifat alir yang sedang dengan nilai indeks pemampatan $18,9 \%$ dan $20,8 \%$ untuk modifikasi dengan pemanasan. Untuk pati modifikasi dengan penambahan asam asetat memiliki sifat alir yang jelek dengan nilai indeks pemampatan $25,2 \%$. Pati singkong alami memiliki sifat alir yang lebih baik dari pati lain karena pati alami ini memiliki ukuran partikel yang seragam serta distribusi partikel merata sehingga memiliki kemampuan menata diri dengan baik dan menghasilkan harga indeks pengetapan yang kecil. Pati modifikasi dengan pentanol memiliki sifat alir yang baik dibandingkan pati modifikasi lain kemungkinan disebabkan oleh tekstur dari partikel pati ini licin dan halus dimana semakin halus tekstur dari partikel maka semakin kecil gaya gesek (friksi) antar partikel sehingga mudah mengalir. Sedangkan untuk pati modifikasi dengan asam asetat memiliki sifat alir jelek kemungkinan disebabkan gaya tarik antar partikel serbuk semakin kuat akibat dari tegangan interfasial pada permukaan padat yang terbasahi cairan karena kurang sempurnanya pengeringan dari pati asetat ini.

Adapun hasil data uji pengetapan pati singkong dapat di lihat pada tabel II di bawah ini.

\section{Tabel II. Hasil data uji pengetapan pati singkong dan amprotab}

\begin{tabular}{cc}
\hline \multirow{2}{*}{ Jenis Amilum } & Pengetapan (\%) \\
\cline { 2 - 2 } & Rata-rata nilai pengetapan \\
\hline 1 & $16,0 \pm 3,29$ \\
2 & $13,2 \pm 2,99$ \\
3 & $20,8 \pm 0,91$ \\
4 & $18,9 \pm 1,52$ \\
5 & $25,2 \pm 1,12$ \\
\hline
\end{tabular}

Keterangan :

$1=$ Amprotab

2 = Pati singkong yang tidak di modifikasi

$3=$ Pati singkong modifikasi dengan pemanasan

$4=$ Pati singkong yang di modifikasi dengan pentanol-1

$5=$ Pati singkong yang di modifikasi dengan asam asetat.

Kompaktibilitas

Massa pati yang dikempa sebesar $700 \mathrm{mg}$, dengan tekanan 1 sampai tekanan 10 . Untuk amprotab sebagai pembanding, pati modifikasi dengan pentanol-1, pati modifikasi dengan asam asetat, penabletan dapat dilakukan pada tekanan 5,6, dan 7. Tekanan di bawah 5 dan tekanan di atas 7 tidak dapat dihasilkan tablet yang baik. Sedangkan untuk pati singkong alami yang tidak di modifikasi sebagai standar dapat di bentuk tablet pada tekanan 6 dan 7. Pati singkong modifikasi dengan pemanasan juga dihasilkan tablet pada tekanan 6 dan 7.

Tablet yang dihasilkan pada tekanan pengempaan 5 dari pati singkong modifikasi dengan pemanasan diperoleh tablet yang capping di mana bagian atas tablet terpisah secara horisontal dari bagian tablet utama. Hal ini disebabkan oleh pati singkong yang di modifikasi dengan pemanasan memiliki sifat serbuk yang terlalu kering sehingga kehilangan daya ikat

Adapun hasil data uji kompaktibilitas dari pati singkong dapat di lihat pada tabel III di bawah ini. 
Tabel III. Hasil Uji Kompaktibilitas dari Pati Singkong dan Amprotab

\begin{tabular}{cccc}
\hline \multirow{2}{*}{$\begin{array}{c}\text { Jenis } \\
\text { Amilum }\end{array}$} & \multicolumn{3}{c}{ Kekerasan $(\mathbf{K g})$} \\
\cline { 2 - 4 } & $\begin{array}{c}\text { Tekanan 5 } \\
\text { Rata-rata nilai } \\
\text { kekerasan }\end{array}$ & $\begin{array}{c}\text { Rata-rata } \\
\text { nilai } \\
\text { kekerasan }\end{array}$ & $\begin{array}{c}\text { Rata-rata nilai } \\
\text { kekerasan }\end{array}$ \\
\hline 1 & $0,73 \pm 0,02$ & $1,53 \pm 0,15$ & $4,52 \pm 0,73$ \\
2 & - & $0,57 \pm 0,01$ & $1,08 \pm 0,09$ \\
3 & - & $0,56 \pm 8,37$ & $0,67 \pm 0,05$ \\
4 & $0,59 \pm 5,47.10^{-3}$ & $.10^{-3}$ & $1,69 \pm 0,29$ \\
5 & $0,56 \pm 4,47.10^{-3}$ & $0,73 \pm 0,15$ & $1,33 \pm 0,08$ \\
\hline
\end{tabular}

Keterangan :

$1=$ Amprotab

2 = Pati singkong yang tidak di modifikasi

3 = Pati singkong modifikasi dengan pemanasan

4 = Pati singkong yang di modifikasi dengan pentanol-1

5 = Pati singkong yang di modifikasi dengan asam asetat. 1

. Untuk nilai kekerasan yang paling tinggi di peroleh dari pati singkong yang dimodifikasi dengan pentanol yaitu sebesar 1,69 kg pada tekanan 7 di karenakan ukuran partikel dari pati modifikasi dengan pentanol ini lebih kecil dan bersifat kohesiv . Sedangkan nilai kekerasan rendah dihasilkan dari pati singkong yang di modifikasi dengan asam asetat pada tekanan 5 sebesar 0,56. Pati singkong ini memiliki kandungan amilopektin yang lebih besar dibandingkan pati yang dihasilkan dari tanaman lain, di mana persentase amilopektin pada tanaman singkong ini sebesar 83\% (Ben dkk., 2007) sehingga sangat potensial untuk dijadikan bahan pengikat pada sediaan tablet khususnya pati singkong yang di modifikasi dengan pentanol-1 yang memiliki karakteristik kekerasan yang lebih baik dibandingkan yang lain.

\section{Ukuran partikel}

Jenis amilum yang berbeda akan memberikan penampakan mikroskop yang berbeda dan bersifat khas.

Adapun hasil pengukuran partikel dari pati singkong dapat di lihat pada tabel IV sebagai berikut:

Tabel IV. Hasil Pengukuran Partikel Pati Singkong dan Amprotab

\begin{tabular}{cc}
\hline Jenis & Ukuran partikel \\
\cline { 2 - 2 } Amilum & Rata-rata ukuran partikel \\
\hline 1 & $18,25 \pm 2,69$ \\
2 & $11,9 \pm 1,28$ \\
3 & $11,85 \pm 1,09$ \\
4 & $11,05 \pm 1,50$ \\
5 & $12,5 \pm 1,90$ \\
\hline Keterangan : \\
$1=$ Amprotab \\
2 = Pati singkong yang tidak dimodifikasi \\
$3=$ Pati singkong modifikasi dengan pemanasan \\
$4=$ Pati singkongyang di modifikasi dengan pentanol-1 \\
$5=$ Pati singkong yang di modifikasidengan asam asetat
\end{tabular}


Pada pati singkong ditambahkan sedikit aquades dan diamati dengan mikroskop optik pada perbesaran 40x. Perhitungan ukuran partikel dengan mengamati partikel amilum dari 5 bidang pandang yaitu dari sisi kanan, kiri, atas, bawah dan tengah. Dimana dari tiap 1 bidang pandang di ambil 5 sampel molekul amilum.

Dari pengamatan yang telah dilakukan, amprotab memiliki ukuran partikel rata-rata $18,25 \mu \mathrm{m}$. Sedangkan untuk pati alami yang tidak di modifikasi memiliki ukuran partikel yang lebih kecil dari amprotab yang terukur sebesar 11,9 $\mu \mathrm{m}$. Untuk pati dengan pemansan memiliki ukuran $11,85 \mu \mathrm{m}$. Pati dengan penambahan pentanol memiliki ukuran partikel paling kecil dibandingkan dengan pati modifikasi lain hal ini disebabkan oleh amilum telah mengalami pemutusan ikatan kimia oleh pentanol menjadi partikel yang lebih kecil sehingga memiliki gaya ikat yang baik akibat adanya gaya kohesif dan terbukti setelah di kempa memiliki kekerasan yang lebih baik dari pati modifikasi dan pati alami. Pati yang mengalami penambahan asam asetat memiliki ukuran partikel yang lebih besar dibandingkan pati modifikasi yang lain, kemungkinan disebabkan oleh adanya substitusi gugus asetat ke dalam struktur molekul pati sehingga memiliki ukuran molekul yang lebih besar yaitu $12,5 \mu \mathrm{m}$. Diharapkan semakin besar ukuran partikel, serbuk akan semakin mudah untuk mengalir dikarenakan besarnya ukuran partikel sebanding dengan gaya gravitasinya yang memudahkan serbuk untuk bergulir ke bawah sesuai dengan gaya beratnya.

\section{KESIMPULAN}

Dari hasil komparasi disimpulkan bahwa karakteristik pati modifikasi lebih baik dan potensial untuk dijadikan sebagai pengikat dan penghancur sediaan tablet dibandingkan dengan pati yang tidak di modifikasi akan tetapi pati standar amprotab memiliki karakteristik yang paling baik.

\section{UCAPAN TERIMA KASIH}

DDPM Direktorat Jenderal Pendidikan Tinggi Kementrian Pendidikan Nasional yang telah memberikan bantuan dana kepada kami sehingga penelitian ini dapat berjalan dengan lancar dan optimal.

\section{DAFTAR PUSTAKA}

Anonim. 1995. Farmakope Indonesia, edisi IV. Departemen Kesehatan Republik Indonesia.Jakarta

Anonim. 2006. Pharmaceutical Excipient, Pharmaceutical Press and American Pharmacist Association, Edited by: Raymond C. Rowe, Paul J. Sheskey and Sian C. Owen, UK.

Artiani P.A dan Avrelina Y.R. 2007. Modifikasi Cassava Starch dengan proses Acetylasi Asam Asetat Untuk Produk Pangan. Jurusan Teknik Kimia, Fakultas Teknik, Universitas Diponegoro

Ayucitra A, Setiawan LEK, Indraswati, N. 2009. Pengaruh Modifikasi Secara Asetilasi Terhadap Karakteristik Pati Sagu Dan Pati Jagung, prosiding Seminar Nasional Teknik Kimia Indonesia-SNTKI 2009, ISBN : 978-979-98300-1-2, 19-20 Oktober 2009, Bandung.

Aziz A, Daik R, Ghani A.M, Daud N. I. N dan Yamin M. B. 2004. Malaysian Journal of Analytical Sciences, Vol 6, No 1. 048-054.

Ben E.S., Zulianis., Halim A. 2007. Studi Awal Pemisahan Amilosa Dan Amilopektin Pati Singkong Dengan Fraksinasi Butanol-Air, jurnal sains dan teknologi farmasi, 12 (1), ISSN: 1410-0177 
Dzulkefly, K., Yaw Koon S, Kassim A, Sharif A dan Abd H A. 2007. Chemical Modification of Sago Starch By Solventless Esterification With Fatty Acid Chlorides, The Malaysian Journal of Analytical Sciences, Vol 11, No 2: 395 - 399

Wattanachant, S., Muhammad, S. K. S., Mat Hashim, D. and Rahman, R. A. 2002. Suitability of sago starch as a base for dual-modification, Songklanakarin J. Sci. Technol., 24(3) : 431-438.

Firdaus F, Mulyaningsih S., Darmawan E. 2006. Rekayasa Pati Dengan Pentanol-1 Dan Khitosan Untuk Peningkatan Kualitas Film Plastik Biodegradable: analisis morfologi, karakteristik mekanik, dan ketahanan air, Proceeding Seminar Nasional Kimia III 2006, ISBN : 979-96595-2-3, 101-111.

Gusnimar A. 2003. Teknik Analisis Kadar Amilosa Dalam Beras. Bul. Tek. Pertan; 8, $82-84$

Ikhsan, M. 1996. Pemakaian Amilum Termodifikasi Sebagai Sediaan Bahan Pembantu Pembuatan Tablet Asam Askorbat Secara Cetak Langsung. Skrips.i sarjana Farmasi universitas Andalas:Padang

Ohwoavworhua, F.O., Alelakun, T.A. 2005. Some Physical Characteristics of Microcrystalline Cellulose Obtained from Row Cotton of Cochlospermuon planchonii, Trop J. Pharm. Res. 4 (2): 501-507.

Onyango C. Mewa EA., Mutahi AW.; dan Okoth MW. 2013. Effect of heat-moisturetreated cassava starch and amaranth malt on the quality of sorghum- cassavaamaranth bread. African Journal of Food Science.,7(5):80-86.

Patel, D.M., Prajupati, D.G., Paten, N.M. 2007 Seed Mucilage from Ocimum americanum Linn. as Disintegrant in Tablets: Separation and Evaluation, Indian. J. Pharm, Sci. 69:433

Rahman, A.M. 2007. Mempelajari Karakteristik Kimia dan Fisik Tepung Tapioka dan Mocal (Modifi ed Cassava Flour) sebagai Penyalut Kacang pada Produk Kacang Salut. Skripsi. Fakultas Teknologi Pertanian. Institut Pertanian Bogor, Bogor.

Sriroth K, Piyachomwan K, Sangseethong K, and Oates C. 2002. Modification of Cassava Starch, Paper presented at X International Starch Convention, 11-14 June 2002, Cracow, Poland.

Syukri, Y dan Firdaus, F. 2009. Studi Potensi Berbagai Pati Tropis Dari Umbi-Umbian Lokal Indonesia Khususnya Ubi Kayu/Singkong (Manihot utilissima Pohl.) Dan Ubi Jalar (Ipomoea batatas Linn.) Sebagai Bahan Baku Pembuatan Eksipien Tablet. Laporan Penelitian Pendahuluan Farmasi FMIPA UII

Voight, R. 1984. Buku Pelajaran Teknologi Farmasi, diterjemahkan oleh soendani noerono, edisi V, gajah mada university press, Yogyakarta.

Widiawan M.E, Nocianitri K.A, Putra K.N. 2013. Karakterisasi Sifat Fisiko-Kimia Pati Talas Kimpul (Xanthosoma Sagittifolium) termodifikasi dengan metode asetilasi, Jurusan Ilmu dan Teknologi Pangan, Fakultas Teknologi Pertania, Universitas Udayana.

Winarno, F.G., 1986, Kimia Pangan dan Gizi, Edisi 2, Penerbit PT. Gramedia, Jakarta, $27-$ 34.

Wlodarski K., Tajber L., Sawicki W. 2016. Physicochemical properties of direct compression tablets with spray dried and ball milled solid dispersions of tadalafil in PVP-VA. Eur. J. Pharm. Biopharm.,109, 14-23. 
